\title{
The Difference in English Proficiency Between Tourism and Engineering Students of Two Asian Universities
}

\author{
Massuline Antonio D. Ligaya, Estrella F. Fajardo, Joung-Hyun Ham, Seungjin Lee
}

\begin{abstract}
This study was conducted to evaluate and compare the level of English proficiency of Tourism and Engineering students in two Asian universities and to examinee how certain factors affect their proficiency in the language. The descriptive technique was applied in this study. Statistical analyses were done using mean, one-way analysis of variance (ANOVA), Turkey's HSD and correlation coefficient. The correlation performed between English proficiency of the respondents and the other variables yielded different results prompting different decisions on hypothesis 1. Hypothesis 2 is rejected. There exists a significant difference between the English proficiency of Tourism and Engineering students. Engineering students of university $A$ have mean scores in English proficiency significantly different or higher than Tourism students of university $A$ and the Engineering and Tourism students of university $B$.
\end{abstract}

Keywords : Attitude Towards English, English Proficiency, Motivation Towards English commas.

\section{INTRODUCTION}

W ith the world becoming increasingly globalized, it is necessary that people from different parts of the world speak a common language - a lingua-franca. English has gradually taken that position. There may be more native speakers of Mandarin and Spanish than English but people living in Europe, Asia, Africa, and South America have English as their second language. What contributed to this were the facts that the United Kingdom, where the modern English language originated, used to be a colonial power that ruled many parts of the continents aforementioned and the rise of English speaking countries, particularly the United States, to political and economic prominence when the colonial period ended.

Given the current trends in both the marketplace and academia, the need to be proficient in the language has grown more apparent. The 8th edition of EF English Proficiency Index revealed that more scientific journals are

Revised Manuscript Received on July 22, 2019.

* Correspondence Author

* Seungjin Lee, Liberal Arts \& Interdisciplinary Studies., Hanseo University, South Koera, tlhanseo@gmail.com

Massuline Antonio D. Ligaya, Liberal Arts \& Interdisciplinary Studies, Hanseo University, South Korea, madligaya@gmail.com

Estrella F. Fajardo, College of Arts and Letters, Bulacan State University, Philippines,Fajardo.benell@gmail.com

Joung-Hyun Ham, Liberal Arts \& Interdisciplinary Studies., Hanseo University, South Korea, aprilham@gmail.com published in English and cited a report that close to sixty percent of all multinational organizations already operate in English. This serves as a confirmation that English is indeed the leading language not only in education but also in business. Proficiency in the language then is required not only to gain access to information, particularly important research findings, but also to catch up to the competition. Therefore, in order to become (and remain competitive) in the business world it is important to gain proficiency in what has become the academic and corporate language - English.

Several studies that were conducted established the clear correlation between English proficiency and employability and income [1], [2], [3], [4]. In addition, as reported in EF's 1 st edition, recruiters and HR managers around the world disclosed in a survey that preference is accorded to candidates with English skills above the local average and receive salaries $30-50 \%$ higher than similarly-qualified candidates without English skills.

Even in countries where English is only a second language or one of the many languages spoken, there are certain kinds of jobs that require English proficiency. These are jobs in industries, like tourism, where communicating with people with different native languages is an integral part of the business. Graduates of Tourism are expected to develop a high level of proficiency in English because success in the industry hinged upon good communication in the chosen lingua-franca. The tourism industry requires effective communication in order to ensure quality and needed performance standards [5], [6]. This makes mastering English a prerequisite for getting a job in the said field [7].

Conversely, there are line of works in non-English speaking regions of the world where becoming conversant in the language is perceived as not necessary. There exists in countries where English is not the first language a pervading belief that to work as an engineer, for example, one need not be good at English. Although there are universities in the said countries where Engineering courses are offered in English (to cater to foreign students), local students would prefer to enroll in the programs delivered in their respective mother tongues. But among the generic skills that Engineers must develop is effective communication which is an essential employability skill in the competitive global work arena [8], [9]. An English needs analysis for Engineers in Taiwan reveals that practitioners in the field face numerous English

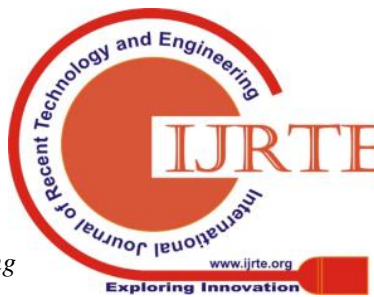


communicative events similar to other Asia-Pacific nations including highly frequent writing and reading events such as email, reports, and memos, while common oral events include meetings, teleconferences, and presentations [10].

Therefore, English proficiency is as important in the field of Engineering as it is in the field of Tourism. However, between the fields of Tourism and Engineering, there seem to be more pressure on the students and practitioners in the former to take English training more seriously than in the latter. It is even a common perception that people in the Tourism industry, because of the nature of their job and business, are more proficient in English than their counterparts in the field of Engineering. Thus, in universities, students enrolled in Tourism are perceived to have better English communication skills than those pursuing Engineering courses.

This study was conducted to evaluate and compare the level of English proficiency of Tourism and Engineering students in two Asian universities not only to determine if there exists a significant difference in their skills in English but also to find out how certain factors affect their proficiency in the language.

Specifically, answers to the following questions were sought.

1. What is the profile of the Tourism and Engineering students in terms of age and number of years studying English?

2. How may each of group of students be described in terms of attitude towards learning English and motivation for learning English?

3. What is the level of English proficiency of each group of students?

4. Do age, number of years studying English, attitude towards learning English, and motivation for learning English significantly affect the English proficiency of Tourism and Engineering students?

5. Is there significant difference in the English proficiency of Tourism and Engineering students?

The following null hypotheses were formulated for this study:

Hypothesis 1: Age, number of years studying English, attitude towards learning English, and motivation for learning English do not significantly affect the English proficiency of Tourism and Engineering students.

Hypothesis 2: There is no significant difference between the English proficiency of Tourism and Engineering students.

\section{MATERIALS AND METHODS}

The technique applied in this study was the descriptive survey research. A total of 399 students from two universities in Asia served as respondents. Table I shows the distribution of respondents.

Table- I: Distribution of Respondents

\begin{tabular}{|c|c|c|}
\hline University A & 97 & 99 \\
\hline University B & 104 & 99 \\
\hline Total & 201 & 198 \\
\hline
\end{tabular}

The questionnaire used for data gathering was adapted from an instrument used in a similar study [11]. The said questionnaire is subdivided into three parts, namely, Part I (Students' Profile); Part II (Attitude and Motivation Towards the English Subject); and Part III (English Proficiency Test).

The English proficiency test is subdivided into the following areas: vocabulary grammar, getting the correct grammatical form, answering question, combining sentences, and word sequencing.

The respondents from the participating universities are divided into 4 groups namely University A-Tourism, University A-Engineering, University B-Tourism, and University B-Engineering. The English proficiency of each group of respondents were measured and compared with one another.

Data processing was done using the Statistical Package for the Social Sciences (SPSS).

The respondents attitude towards learning English, motivation for learning English and level of English proficiency were analyzed using mean. The scales in table II were used for the interpretation.

Table- II: Name of the Table that justify the values

\begin{tabular}{|c|c|c|l|}
\hline \multirow{2}{*}{ Scale } & \multicolumn{3}{|c|}{ Verbal Interpretation } \\
\cline { 2 - 4 } & Attitude & Motivation & $\begin{array}{l}\text { English } \\
\text { Proficiency }\end{array}$ \\
\hline $3.6-4.0$ & $\begin{array}{c}\text { Highly } \\
\text { Positive }\end{array}$ & $\begin{array}{c}\text { Highly } \\
\text { Motivated }\end{array}$ & $\begin{array}{l}\text { Highly } \\
\text { Proficient }\end{array}$ \\
\hline $2.6-3.5$ & Positive & Motivated & Proficient \\
\hline $1.6-2.5$ & $\begin{array}{c}\text { Moderately } \\
\text { Positive }\end{array}$ & $\begin{array}{c}\text { Moderately } \\
\text { Motivated }\end{array}$ & $\begin{array}{c}\text { Moderately } \\
\text { Proficient }\end{array}$ \\
\hline $1.0-1.5$ & Negative & Low & Less Proficient \\
\hline
\end{tabular}

The comparative analysis of their level of proficiency was performed using their mean scores. The mean scores of Tourism and Engineering students in both respondent-universities were computed separately resulting to four sets of unrelated mean scores. For the purpose of determining whether differences between the computed mean scores are statistically significant, the one-way analysis of variance (ANOVA) was used.

After performing the one-way analysis of variance, it was discovered that there existed significant differences in the mean scores. When results of ANOVA indicate significant differences in the mean scores, a post hoc test should be performed in order to determine where the differences lie [12]. In this study, such was done using Turkey's HSD (Honestly Significant Difference).

The relationship between age, number of years, attitude towards learning English, motivation for learning English, and English proficiency were estimated using correlation coefficient to help explain the findings. 


\section{RESULTS AND DISCUSSIONS}

\section{A. Respondents' Age and Number of Years Studying English}

Table III shows the average age of the student-respondents as well as the average number of years they have been studying English. The Engineering students of university B have the highest average age (21.81) and the Tourism students in University A have the lowest (18.86).

The ones who have been studying English the longest are the Engineering students of university A (13.51) followed by the Tourism students from the same university. Tourism and Engineering students from university A, in general, have been studying the language longer than their counterparts from university B.

Table- III: Distribution of Respondents

\begin{tabular}{|l|c|c|}
\hline & $\begin{array}{c}\text { Average } \\
\text { Age }\end{array}$ & $\begin{array}{c}\text { Average Number of } \\
\text { Years Studying English }\end{array}$ \\
\hline University A-Tourism & 18.86 & 13.38 \\
\hline University A-Engineering & 20.98 & 13.51 \\
\hline University B-Tourism & 20.26 & 9.82 \\
\hline University B-Engineering & 21.81 & 9.97 \\
\hline
\end{tabular}

\section{B. Attitude Towards Learning English}

As reflected in Table IV, Tourism students of universities A and B and the Engineering students of university A have shown positive attitude towards learning English while the Engineering students of university B, with a mean score of 1.727 , are moderately positive only. At 2.929 , the Engineering students from university A have the highest mean score.

Table- IV: Descriptive Measure of Attitude Towards Learning English

\begin{tabular}{|l|c|c|}
\hline & $\begin{array}{c}\text { Average } \\
\text { Mean }\end{array}$ & $\begin{array}{c}\text { Verbal } \\
\text { Interpretation }\end{array}$ \\
\hline University A-Tourism & 2.748 & Positive \\
\hline University A-Engineering & 2.929 & Positive \\
\hline University B-Tourism & 2.628 & Positive \\
\hline University B-Engineering & 1.727 & Moderately Positive \\
\hline
\end{tabular}

Table IV shows contrasting results. While in university A, Engineering students were found to view leaning English more positively than Tourism students, in university B, it is the Tourism students who have a more positive attitude towards learning the language than Engineering students.

\section{Motivation for Learning English}

As shown in Table $\mathrm{V}$, all Tourism students from both universities are moderately motivated towards learning English. The group with the highest mean score is University A-Tourism (2.328) and the one with the lowest mean score is University A-Engineering (2.132).

Table- V: Descriptive Measure of Respondents' Motivation Towards Learning English

\begin{tabular}{|l|c|c|}
\hline & $\begin{array}{c}\text { Average } \\
\text { Mean }\end{array}$ & $\begin{array}{c}\text { Verbal } \\
\text { Interpretation }\end{array}$ \\
\hline University A-Tourism & 2.328 & Moderately Motivated \\
\hline
\end{tabular}

\begin{tabular}{|l|l|l|}
\hline University A-Engineering & 2.132 & Moderately Motivated \\
\hline University B-Tourism & 2.211 & Moderately Motivated \\
\hline University B-Engineering & 2.292 & Moderately Motivated \\
\hline
\end{tabular}

\section{English Proficiency}

The following were the areas of English proficiency that were measured in this study: vocabulary of grammar (VG); getting the correct grammatical form (GCGF); answering questions (AQ); combining sentences (CS); and word sequencing (WS).

The abbreviations for the areas of English proficiency in the preceding paragraph are used in Tables VI and VII.

Tables VI and VII reveal that Tourism and Engineering students of university A are "proficient in English while their counterparts from university B are considered moderately proficient. The Engineering students of university A tallied the highest computed mean at 3.376, followed by the Tourism students from university A with 3.08. Tourism students of university B has the lowest mean score of 2.186.

Table- VI: Descriptive Measure of Respondents' English

Proficiency (University A - Tourism and Engineering)

\begin{tabular}{|l|c|c|c|c|}
\hline & Mean & $\begin{array}{c}\text { Verbal } \\
\text { Interpretation }\end{array}$ & Mean & $\begin{array}{c}\text { Verbal } \\
\text { Interpretation }\end{array}$ \\
\hline & \multicolumn{3}{|c|}{ Tourism } & \multicolumn{2}{|c|}{ Engineering } \\
\hline VG & 3.56 & Proficient & 3.91 & Highly Proficient \\
\hline GCGF & 2.98 & Proficient & 3.09 & Proficient \\
\hline AQ & 3.36 & Proficient & 3.80 & Highly Proficient \\
\hline CS & 2.56 & $\begin{array}{c}\text { Moderately } \\
\text { Proficient }\end{array}$ & 3.05 & Proficient \\
\hline WS & 2.29 & $\begin{array}{c}\text { Moderately } \\
\text { Proficient }\end{array}$ & 3.03 & Proficient \\
\hline Average & 3.08 & Proficient & 3.376 & Proficient \\
\hline
\end{tabular}

As can be gleaned from the tables, the Engineering students from university A topped the English proficiency test (3.376) in all the 5 different areas tested (vocabulary of grammar, getting correct grammatical form, answering questions, combining sentences, and word sequencing). They are highly proficient in the areas vocabulary of grammar and answering questions.

Table- VII: Descriptive Measure of Respondents' English Proficiency (University B - Tourism and Engineering)

\begin{tabular}{|l|c|c|c|c|}
\hline & Mean & $\begin{array}{l}\text { Verbal } \\
\text { Interpretation }\end{array}$ & Mean & $\begin{array}{c}\text { Verbal } \\
\text { Interpretation }\end{array}$ \\
\hline VG & \multicolumn{3}{|c|}{ Tourism } & \multicolumn{2}{|c|}{ Engineering } \\
\hline GCGF & 2.63 & Proficient & 2.51 & $\begin{array}{c}\text { Moderately } \\
\text { Proficient }\end{array}$ \\
\hline AQ & 3.40 & $\begin{array}{c}\text { Moderately } \\
\text { Proficient }\end{array}$ & 2.31 & $\begin{array}{c}\text { Moderately } \\
\text { Proficient }\end{array}$ \\
\hline CS & 1.44 & Less Proficient & 3.36 & Proficient \\
\hline WS & 1.42 & Less Proficient & 1.57 & Less Proficient \\
\hline VG & 2.186 & $\begin{array}{c}\text { Moderately } \\
\text { Proficient }\end{array}$ & 2.232 & $\begin{array}{c}\text { Moderately } \\
\text { Proficient }\end{array}$ \\
\hline
\end{tabular}

The areas where Tourism students from university A preformed best are in vocabulary of grammar (3.56) and answering questions (3.36) which were both interpreted as proficient.

In the areas combining sentences and word sequencing, Tourism students of university B got mean scores 
of 1.44 and 1.42, respectively and Engineering students, also of university B, 1.57 and 1.41, respectively. All scores were interpreted as less proficient. However, the said groups turned out to be proficient in answering questions with Tourism students scoring 3.40 and the Engineering students 3.36 .

Tables VI and VII reveal that in both universities (A and B), Engineering students have better English proficiency skills than Tourism students.

\section{E. Analysis of the Relationship Between Age, Number of Years Studying English, Attitude Toward Leaning English, Motivation for Learning English, and English Proficiency}

Table VIII indicates that among Engineering students of universities $\mathrm{A}$ and $\mathrm{B}$, the number of years they studied English was found to be significantly correlated to certain areas of English proficiency. Negatively correlated to certain areas of English proficiency of Tourism students in both universities is their age.

Table- VIII: Correlation Analysis

\begin{tabular}{|c|c|c|c|c|c|c|c|c|}
\hline & \multirow[t]{2}{*}{$\mathbf{N}$} & \multirow[t]{2}{*}{ Mean } & \multirow[t]{2}{*}{ SD } & \multirow[t]{2}{*}{ Std Error } & \multicolumn{2}{|c|}{$\begin{array}{l}95 \% \text { Confidence Interval } \\
\text { for Mean }\end{array}$} & \multirow[t]{2}{*}{ Minimum } & \multirow[t]{2}{*}{ Maximum } \\
\hline & & & & & Lower Bound & Upper Bound & & \\
\hline University A-Engineering & 99 & 16.88 & 3.879 & .390 & 16.11 & 17.65 & 7 & 24 \\
\hline University A-Tourism & 97 & 15.04 & 3.755 & .381 & 14.28 & 15.80 & 5 & 24 \\
\hline University B-Engineering & 100 & 11.16 & 3.302 & .330 & 10.50 & 11.82 & 5 & 21 \\
\hline University B-Tourism & 104 & 11.04 & 3.726 & .365 & 10.31 & 11.76 & 5 & 22 \\
\hline Total & 400 & 13.48 & 4.443 & .222 & 13.05 & 13.92 & 5 & 24 \\
\hline
\end{tabular}

*Correlation is significant at the 0.05 level (2-tailed)

**Correlation is significant at the 0.01 leve(2-tailed)

It is only among Tourism students from university B that attitude towards learning English and motivation for learning English were found to be positively correlated to English proficiency.

The Engineering students from university A have the highest average mean for attitude towards learning English. This is an indication that this group possesses the most positive attitude toward studying the language. But it can be argued that the group University A-Tourism are the most motivated among the student-respondents having scored the highest average mean in the area "Motivation Towards

Leaning English." What could then serve as the more plausible explanation for the Engineering students from university A having the best proficiency score is the number of years they have been studying English. Table 3 shows that students taking up Engineering in University A have the highest mean average in terms of number of years spent studying English.

The analysis in Table VIII indicates a positive correlation between number of years studying English and English proficiency which means that the more time study English

Table- IX: Analysis of the Means

\begin{tabular}{|c|c|c|c|c|c|c|c|c|}
\hline & $\mathbf{N}$ & Mean & SD & Std Error & $\begin{array}{r}95 \% \text { Conf } \\
\text { fo }\end{array}$ & $\begin{array}{l}\text { nce Interval } \\
\text { ean }\end{array}$ & Minimum & Maximum \\
\hline & & & & & Lower Bound & Upper Bound & & \\
\hline University A-Engineering & 99 & 16.88 & 3.879 & .390 & 16.11 & 17.65 & 7 & 24 \\
\hline University A-Tourism & 97 & 15.04 & 3.755 & .381 & 14.28 & 15.80 & 5 & 24 \\
\hline University B-Engineering & 100 & 11.16 & 3.302 & .330 & 10.50 & 11.82 & 5 & 21 \\
\hline University B-Tourism & 104 & 11.04 & 3.726 & .365 & 10.31 & 11.76 & 5 & 22 \\
\hline Total & 400 & 13.48 & 4.443 & .222 & 13.05 & 13.92 & 5 & 24 \\
\hline
\end{tabular}

\section{E. Analysis of Variance}

As can be gleaned from table IX, the mean scores of University A-Engineering (16.88) and University B -Tourism (11.04) are the highest and lowest, respectively. University A-Engineering has higher mean score (16.88) than University B-Engineering (11.16) and University A-Tourism has a higher mean score (15.04) than University B-Tourism (11.04).

Also note that University A-Engineering has higher mean score (11.04) than University A-Tourism (15.04) and University B-Engineering (11.16) has higher mean score than University A-Tourism (11.04). Collectively, Engineering and Tourism students of University A have higher mean scores than their counterparts from University B.

NYSE - Number of Years Studying English

the more proficient in the language they become.

The same table shows a negative correlation between age and English proficiency. Such inverse relationship indicates that the younger the students are, the lesser proficient are they in the language. It is not the age per se that affects proficiency but being younger means the lesser time they had to learn the language as compared to those who are older than they are. It should be noted that the Engineering students in both respondent universities who came 
out to be more proficient in English than their Tourism counterparts have not only studied English longer, as indicated by their higher average years studying English, but they are also, on the average, older. For non-native English speakers, the younger they start learning English the better. Non-native English speaking students who started their learning career at an early age usually have higher English language proficiency than students who started at a later age [13].

A study on the relationship between time spent on learning English and proficiency in the language verified that the number answering of years studying English significantly predict English ability [14]. On the other hand, the lack of time to study the language is considered a barrier in attaining proficiency in the language [15].

Table- X: Analysis of Variance (ANOVA)

\begin{tabular}{|c|c|c|c|c|c|}
\hline & $\begin{array}{c}\text { Sum of } \\
\text { Squares }\end{array}$ & Df & $\begin{array}{c}\text { Mean } \\
\text { Square }\end{array}$ & F & Sig. \\
\hline Between & 2538.24 & 3 & 846.081 & 62.77 & .000 \\
\hline
\end{tabular}

\begin{tabular}{|c|c|c|c|c|c|}
\hline Groups & 3 & & & 1 & \\
\hline $\begin{array}{c}\text { Within } \\
\text { Groups }\end{array}$ & $\begin{array}{c}5337.66 \\
7\end{array}$ & 396 & 13.479 & & \\
\hline Total & $\begin{array}{c}7875.91 \\
0\end{array}$ & 399 & & & \\
& & & & \\
\hline
\end{tabular}

The results of the analysis of variance (ANOVA) shown in Table $\mathrm{X}$ indicates that there exist significant differences in the mean scores in grammatical proficiency of Tourism and Engineering students of the respondent-universities. This is shown by the significance of $\mathrm{F}$ (sig. $=.000$ ) which is way above the set level of .05.

Post hoc analysis was performed to find out where among the compared mean scores the differences noted in the ANOVA analysis exists at .05 level of significance. The mean difference score with superscript asterisk $\left({ }^{*}\right)$ indicate that significant difference exist between the pairs of scores.

Table XI shows that the mean score in English proficiency of university A Engineering students is significantly different

Table- XI: Multiple Comparison

\begin{tabular}{|c|c|c|c|c|c|c|}
\hline \multirow[t]{2}{*}{ (I) Course } & \multirow[t]{2}{*}{ (J) Course } & \multirow{2}{*}{$\begin{array}{c}\text { Mean } \\
\text { Difference } \\
(\mathbf{I}-\mathbf{J})\end{array}$} & \multirow[t]{2}{*}{$\begin{array}{l}\text { Std. } \\
\text { Error }\end{array}$} & \multirow[t]{2}{*}{ Sig. } & \multicolumn{2}{|c|}{$\begin{array}{l}\text { 95\% Confidence } \\
\text { Interval }\end{array}$} \\
\hline & & & & & $\begin{array}{l}\text { Lower } \\
\text { Bound }\end{array}$ & $\begin{array}{l}\text { Upper } \\
\text { Bound }\end{array}$ \\
\hline \multirow[t]{3}{*}{ University A- Engineering } & University A-Tourism & $1.838^{*}$ & .525 & .003 & . 48 & 3.19 \\
\hline & $\begin{array}{l}\text { University } \\
\text { B-Engineering }\end{array}$ & $5.719 *$ & .521 & . 000 & 4.38 & 7.06 \\
\hline & University B- Tourism & $5.840^{*}$ & .516 & .000 & 4.51 & 7.17 \\
\hline \multirow[t]{3}{*}{ University A- Tourism } & $\begin{array}{l}\text { University } \\
\text { A-Engineering }\end{array}$ & $-1.838^{*}$ & .525 & . 003 & -3.19 & -.48 \\
\hline & University B Engineering & $3.881 *$ & .523 & .000 & 2.53 & 5.23 \\
\hline & University B Tourism & $4.003 *$ & .518 & .000 & 2.67 & 5.34 \\
\hline \multirow[t]{3}{*}{ University B-Engineering } & $\begin{array}{l}\text { University } \\
\text { A-Engineering }\end{array}$ & $-5.719^{*}$ & .521 & .000 & -7.06 & -4.38 \\
\hline & University A-Tourism & $-3.881 *$ & .523 & .000 & -5.23 & -2.53 \\
\hline & University B-Tourism & .122 & .514 & .995 & -1.21 & 1.45 \\
\hline \multirow[t]{3}{*}{ University B-Tourism } & $\begin{array}{l}\text { University } \\
\text { A-Engineering }\end{array}$ & $-5.840 *$ & .516 & .000 & -7.17 & -4.51 \\
\hline & University A-Tourism & $-4.003 *$ & .518 & .000 & -5.34 & -2.67 \\
\hline & $\begin{array}{l}\text { University } \\
\text { B-Engineering }\end{array}$ & -.122 & . .514 & .995 & -1.45 & 1.21 \\
\hline
\end{tabular}

\section{CONCLUSION}

The correlation analysis performed between English proficiency of the respondents and the other variables yielded different results prompting different decisions on hypothesis 1.

Number of years studying English contributed significantly to English proficiency of Engineering students in universities A and B. Therefore, for this group, hypothesis 1 is rejected in terms of the said variable. However, for the same group of respondents, hypothesis 1 is accepted for age, attitude towards English, and motivation for learning English. These variables do not affect their performance in the language.

There exists an inverse relationship between English 
proficiency of Tourism students of universities A and B and the variable age. Therefore, for this group, hypothesis 1 is rejected in terms of the said variable. For the same group of respondents, hypothesis 1 is accepted for number of years studying English since the said variable has no effects on their proficiency in English.

While the variables attitude towards English and motivation for learning English have effects on the performance of Tourism students of university B in English they have none on that of Tourism students of University A, therefore, hypothesis 1 is rejected on the latter and accepted on the former.

Hypothesis 2 is rejected. There exists a significant difference between the English proficiency of Tourism and Engineering students. Engineering students of university A

or higher than that of those enrolled in the Tourism course of the same university and the Engineering and Tourism students of university B. Also, the mean scores in English proficiency of Tourism students from university $A$ is significantly different or higher than that of both the Engineering and Tourism students of university B. There was no significant difference between the mean scores in grammatical proficiency of Engineering and Tourism students of university B.have mean scores in English proficiency significantly different or higher than Tourism students of university A and the Engineering and Tourism students of university B.

The computed mean score of Engineering students of university B is higher that of the Tourism students of the same university although it is not considered significantly different when the multiple comparison was made.

\section{REFERENCES}

1. H.L. Blake, S. Mcleod, S. Verdon, F. Fuller, "The relationship between English proficiency and participation in higher education, employment and income" Int J Speech Lang Pathol., 20(3), 202-215, 2018.https://doi $: 10.1080 / 1754907.2016 .1229031$

2. S.H. Ting, E. Marzuki, K.M. Chuah, J. Misieng, C.Jerome, "Employers' views on the importance of English proficiency and communication skill for employability in Malaysia Indonesian Journal of Applied Linguis- tic, 7(2), 315-327, 2017. https://doi:dx.doi.org/10.17509/ijal.v7i2.8132.

3. Y. Zhen, "The effects of English proficiency on earnings of U.S. foreign-born Migrants: Does Gender matter?" Journal of Finance and Economics, 1(1), 2013. https://doi:10.12735/jfe.vlilp27

4. Tam, K.W., Page, L., "Effects of language proficiency on labor, social and health outcomes of immigrants in Australia" Economic, Analysis \& Policy 2016,https://dx.doi.org/10.1016/j.eap.2016.08.003

5. M.K. Bobanovic, J. Grzinic, "The importance of English language skills in tourism sector: A comparative study of students/employees perceptions in Croatia" Almatourism-Journal of Tourism, Culture and Territorial Development., 2 (4), 1-14, 2013. https://doi:10.6092/isnn20 $36-5195 / 2476$

6. N. Prachanant, "Needs analysis on English language use in tourism industry." Procedia - Social and Behavioral Sciences, 66 117-125, 2012. https://doi:10.1016/j.sbpro.2 012.11 .253

7. S. Younis, M. Abdel Latif, "English language preparation of tourism and hospitality undergraduates in Egypt: Does it meet their future workplace requirements?" The Journal of Hospitality Leisure Sport and Tourism, 11(2), 93-100.2012. https://doi.org/10.1016/j.jhlste.2012.05.001

8. A. Clement, T. Murugavel, "English for employability: A case study of the English language training need analysis for engineering stu-dents in India" English Language Teaching 8(2), 2015. https://doi:10.5 539/elt.v8n2p116

9. P. Sureeyatanapas, A. Boonma, S. Talangkum, "English proficiency requirements for engineering graduates at private organizations in Thai- land" KKU Engineering Journal, 43(S1) 35-39, 2016.https://doi:10.4 456/kkuenj.2016.64

10. P. Spence, G.Z. Liu, "Engineering English and the high-tech industry: A case study of an English needs analysis of process integration engi- neers at a semiconductor manufacturing company in Taiwan." English for Specific Purposes, 32 (3), 97-109, 2013.https.//doi.org/10.1016/j.e sp. 2012.11.003

11. E. Fajardo, "Language Attitude, Motivation, Learning and Thinking Styles As Correlates of Grammar Proficiency of College Students" Master's thesis]. Bulacan State University, 2011.

12. R. Miller, Beyond Anova, Basics of Applied Statistics, Chapman \& Hall/CRC: 1998.

13. Z.S. Ibrahim, M.A. Hassali, F. Saleem, H. Aljadhey, "Perceptions and barriers towards English language proficiency among pharmacy undergraduates at Universiti Sains, Malaysia" Pharmacy Education 13 (1), 151-156, 2013.https://doi:10.1016/j.sapharm.2014.07.098

14. C. Magno, "Korean Students' Language Learning Strategies and Years of Studying English as Predictors of Proficiency in English" Teaching English to Speakers of Languages Journal, 2 (1): 39-61, 2008.https://doi. org/10.1111/j.1944-9720.1997.tb02343.x

\section{AUTHORS PROFILE}

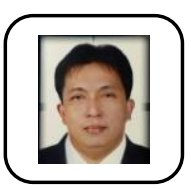

Dr. Massuline Antonio D. Ligaya is currently working as Assistant Professor at Hanseo University in South Korea. He has been in the academe working as school administrator and classroom teacher for 30 years. His areas of interests are Language, Literature, Educational Management, and Research. He has 5 works presented at international conferences and has published 4 papers in indexed-international journals. $\mathrm{He}$ maintains a website (madligaya.com) where he publishes his research works and other writings in both English and Filipino.

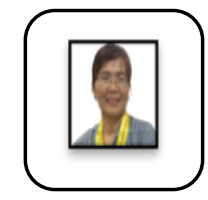

Mrs. Estrella F. Fajardo is an Associate Professor at Bulacan State University. She is a lecturer, a trainer, a book writer, and a researcher. She has a Master's Degree in English and is currently pursuing her Doctorate in English Language and Literature. She has presented several papers in international conferences and published 1 of her studies in an indexed-international journal. Presently, she is the department head of the Student Publications and Information of the university where she works.

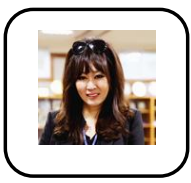

Dr. Joung-Hyun Ham is the Vice-President for External Affairs of Hanseo University in South Korea. She majored in Pedagogy at University of Bridgeport where she is also currently connected with as adjunct professor. She completed the programs "Kennedy School Executive Eduation" and "Project Zero Classroom" at Harvard University as well as University of Connecticut's "Confratute Enrichment Teaching and Learning." Her areas of interests are English Education, and Multiple Intelligences. She has published several papers in indexed-international journals.

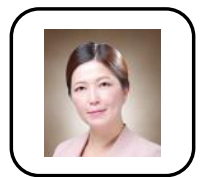

Dr. Seungjin Lee is an assistant professor at Hanseo University in South Korea. She holds the position director of the Liberal Arts Education division. She majored in Education Measurement and Statistics at the Florida State University. Her research interests lie in the application of statistical methodology in the areas of education and psychology. Her areas of interests include advanced statistical data analytic techniques as hierarchal linear model, structural equation modelling, and meta-analytic techniques. 